\title{
CHILD DEVELOPMENT UNIT FOR GOULBURN
}

\section{Plans announced}

A number of government and voluntary agencies have announced plans for the establishment of a joint agencies Child Development Unit in Goulburn. The unit is designed to help children and families under stress. The service will be available to people of the Goulburn district, and other centres in the South Eastern Region.

The agencies co-operating in the establishment of this service to children and families are: the Health Commission of N.S.W., the N.S.W. Department of Education, the Department of Youth and Community Services, the Catholic Family Welfare Bureau, the Anglican Church Diocese of Canberra and Goulburn, the Salvation Army, the South East N.S.W. Child and Family Service, and the Goulburn College of Advanced Education.

The Child Development Unit will provide an assessment, diagnostic and management service to children under stress and their families. These services will also be available to children experiencing learning problems and developmental difficulties.

Day basis

While it is expected that clients from Goulburn and district will attend the Unit on a day basis, it will also be possible for children and families to "live-in" while assessment is taking place. Residential accommodation will be available through the facilities of both the Catholic and the Anglican Churches.

It is expected that children and/or families may be referred to the Child Development Unit through their schools, their family general practitioner, the Community Health Services, a District Officer of the Department of Youth and Community Services or through any member of the church clergy.

The plan is for the Unit to conduct a comprehensive assessment of a child's problem, and then to work with the child, the family and local referring agencies in remedying that problem. Wherever possible, the emphasis will be on treating the child and family in their home and community environment.

However, the services of the Unit will also be available to assist children where families have broken up and there is nowhere for the children to go. The Child Development Unit will provide an assessment service for the voluntary child care agencies to assist them in identifying the needs of such children. The Unit will also advise the child care agencies on what type of family environment to look for in their attempts to find homes for such children.
Despite the Unit's initial emphasis on offering service to children and families in crisis, over a period of time the Unit would hope to be able to of fer educational programmes for parents and families. Such programmes would be aimed at enhancing the value of the family as a social unit.

It is intended that the unit will of fer the services of a Senior Guidance Officer, School Counsellors and a Resource Teacher (from the Education Department); a paediatrician, medical officer, psychologist, social worker, speech therapist, psychiatrist and mental retardation counsellor (from the Health Commission); District Officers (from Youth and Community Services) as well as counsellors and social workers employed by the Church agencies.

\section{Management committee}

Although established on the initiative of the Regional Director of Health (Mr. Frank Nicholls) and the Regional Director of Education (Mr. Brian Gillett), the operation of the Unit will be guided by a Management Committee comprising of representatives of each of the participating agencies.

The Management Committee comprises Father Phibbs (Catholic Church), Archdeacon Woodwell (Anglican Church), Major Pearse (Salvation Army), Mr. Brian Reid (South East N.S.W. Child and Family Service), Mr. Don Stuart (Youth and Community Services), Mr. Paul Morrow (Goulburn College of Advanced Education), Mr. Bill Brewer (Education), Dr. Isobel Patterson (Health Commission) and Mr. Greg McIntyre (Chairman). The Chairman elect for 1978 is Mr. Bill Brewer.

\section{Single co-ordinator}

The participating agencies have agreed to accept a single-Co-ordinator for the joint venture who will be responsible to the Management Committee for the operation of the unct and the co-operative activity of the different staff.

The Co-ordinator will be Mr. Walter Howe, the newly appointed Senior Guidance Officer, who will commence employment in the Unit on the 3rd January 1978.

The Child Development Unit will be located in the Health Commission's Regional Resource Centre, on the corner of Verner and Cowper Streets, Goulburn. Any inquiries concerning the service can be directed to $\mathrm{Mr}$. Greg McIntyre at that location (telephone 04821 6244). 


\section{R E S I D E N T I A L C A R E I N GOULBURN DEVELOPING - Anglican Iniatives}

\section{First home}

The first residential child care home was opened in the Diocese in Young in 1927 but the major development came in Goulburn from a Children's Home started by the Cathedral parish in 1929.

The home in Young closed in the early 1930's and the Goulburn Children's Home became a Diocesan institution, outgrew its original site and moved in 1937 to the present site in Cowper Street, and grew until the huge property, now comprising 6 significant buildings became the St. Saviour's Children's Home.

\section{Community of sisters}

From 1929-1933 a Community of Sisters from Nyngan conducted the institution, and from 1933 to 1968 the Sisters of the Community of the Holy Name managed the operations.

In 1957, as the result of a bequest, the Bungarimbil Farm Home for Boys was established and it operates still on the property, but now in special purpose designed building offering accommodation for 16 boys. The Home is 12 miles out of Tumbarumba.

When the Sisters of the Community of the Holy Name withdrew from Goulburn their recommendation included that the Diocese should use house parents and should establish Family Group Homes.

\section{Investigation}

After much investigation, a family group home to accommodate 8 children and to be managed by house parents was opened in Wagga Wagga and was named "Birralee".

Since 1971 residential child care was being conducted in only two buildings on the Goulburn site.

a. A congregate children's home, still known as St. Saviours, operating in 130 Cowper Street, and capable of accommodating up to 40 children.

b. A girls' student Hostel, known as St. Margaret. This was closed in 1972.

The cost of residential child care was a constant concern to the Diocese.
The quality of care, the suitability of staff, the physical and social arrangements of caring, were of high priority. It was not until 1975 that the appropriateness of the services of fered were seriously challenged.

The basic question then asked was whether this was the best way to care for the children being presented.

A social worker was engaged to critically examine the whole operation and was encouraged to make suggestions as to how we could better care for each of the children in residence. The resultant report highlighted, that for many, there were better alternative types of care and that our services were so often not appropriate.

\section{Dramatic changes}

Dramatic changes have followed:-

1. A foster care programme was instituted which decreased the number of children in St. Saviours Goulburn and placed the 5 children who were in residence at Birralee in Wagga Wagga with substitute families.

2. A joint application was made with the Salvation Army, for the funding of a pilot programme of the alternatives to residential care programme which was successful. The offer was left open for the Roman Catholic Church to join the regional programme which was later accepted and two years have been spent in working together to develop alternatives to residential care.

3. The home at Wagga Wagga was vacant for 10 months and, as no children could be found, the home was sold in June 1976 to the Department of Youth and Community Services to provide accommodation for handicapped children in the region to enable them to attend special education facilities in Wagga Wagga.

4. A family group home was established in Goulburn by renovating one of the buildings on the St. Saviour's site to accommodate 7 State wards from the Goulburn area. With the mother deceased and the father in prison, the family group home enabled the children of the family to be kept together. 
5. The congregate care home is to become a neighbourhood centre, offering-

(a) Full day care (in the Marmot hall)

(b) Crisis accommodation for children

(c) Family refuge for mother and/or father with children -3 self-contained units for parents and children

(d) A base for-

(i) Home maker service and training

(ii) Foster parent training programme

(iii) Family day care

(iv) Family counselling services

(v) Holiday and after school programme

(vi) Community meeting rooms and activities

6. Assessment unit for children's home admissions.

7. Working associations with other residential children's homes and plans for further development of regional programmes to support children and family.

8. The former St. Margaret's Hostel has been renovated to be a child development unit for the South East Region of New South Wales. This is an exciting development as it brings together New South Wales Health Commission, Education Department, Departinent of Youth and Community Services, Anglican, Roman Catholic, Salvation Army, the only established residential child care agencies in the region, the Uniting Church, and, initially, South Eastern New South Wales Child and Family Services. An outline of the proposed unit is attached. A number of staff have already been appointed by Health Commission, Education Department and a Board of Management representative of the above organisations has been constituted.

This unit has the potential to provide diagnostic and assessment services, remedial and therapeutic programmes for both child and families, and the skills, personnel and community involvement to help develop supportive services across the region.

\section{Threatened}

While the Diocesan Bishop-in-Council, staff and supporters of the residential children's homes were threatened with the prospects of changes in our children's homes, it is now widely accepted that the new programmes are more effective and appropriate, and, for the first time, will also be remedial and preventive rather than just being an ambulance type service. Further, the programme has moved from being primarily child centred to now include family and community orientation. The Church which previously worked within its own structure is now involved with other Church, Community and Government groups to develop an integrated care arrangement.

\section{ALICE EMPLOYS CHILDRENS SERVICES OFFICER}

from Bob Gaff Alice Springs

Alice Springs Town Council have taken up a grant from the Office of Child Care and have employed a Children's Services Developmental Officer to work in the Alice Springs area. This is a 2 year appointment and it is expected it will lead on to a number of applications to the Office of Child Care for support for children's services based on a neighbourhood concept.

In the broader scene much work is being done in preparation for the change of responsibility to the Northern Territory Legislative Assembly from July 1 of the whole range of services which includes the whole Welfare Service area.

The Central Australian Aborigines' Congress are working to develop a far-reaching program of services to children and their families in Alice Springs. This will again be in association with grants through the Office of Child Care.

The Northern Territory Council of Social Services is working towards providing a liaison structure for the Community Services area after its change to the Legislative Assembly control. The period between now and the establishment of a working relationship under the Legislative Assembly control promises to be an interesting one.

\section{INTEGRATED SERVICES SOUGHT}

from

Peter Quirk - Director of N.S.W. Association of Child Care Agencies writes -

The situation in N.S.W. is one of much specific negotiation but close contact with the State Department of Youth and Community Services who are at present considering a draft proposal for a policy towards one Government Children's Homes which they insist on still 
calling voluntary children's Homes in N.S.W. We published late in 1977 a paper which was meant to stimulate discussion and question the level of State Government support for the non-Govt. sector, and there has been a draft paper prepared within the Department and considered by us in a Conference setting, which enabled us to pass comment and prepare a response to it. That response has been delivered to our relevant Minister by a deputation from the N.S.W. Association. We hope from that to achieve the easy flow of a Cabinet minute that we know has been prepared through the system so that in our Budget this year in N.S.W. there might be a better system. We are seeking an integrated Child Care Service in N.S.W. involving the non-Govt. sector in a closer relationship than it has been in the past with the State and certainly a greater acceptance of financial responsibility from the State Government.

The Association itself seems to be gathering strength. We have conducted Child Care Workers' Seminars, two to date, and they have been most successful and have attracted many people. Obviously a high point for discussion is the question of working with adolescents, the treatment of adolescents and the development of centres to deal with or look at the problems of the over 12 Group as distinct from the action that the State Govt. nas been sponsoring through Youth Refuges and the like.

\section{Continuing reduction}

Generally, the situation in the State is one of a continuing slight reduction in numbers of children in care. At the last count there were about 1700 children in residential care in agencies that were members of the Association.

We did have one or two agencies not members, late in 1977 but they have re-joined the Association so at the present time to our knowledge everybody conducting a Residential Childrens Unit is a member of the State Association. Generally, while the State Government has a policy at the present time of not providing funding to member agencies or as they call them, voluntary children's homes, there have been a couple of places that have got Federal Government funding. One of those is the Waitara Mercy Life Centre which is going through a complete re-building process and that is really worth looking at. Another move of the Uniting Church into a pre-school Kindergarten and treatment Centre for parents with the Child Abuse situation has also received funding from the Office of Child Care. We hope they will join our Association as a member.

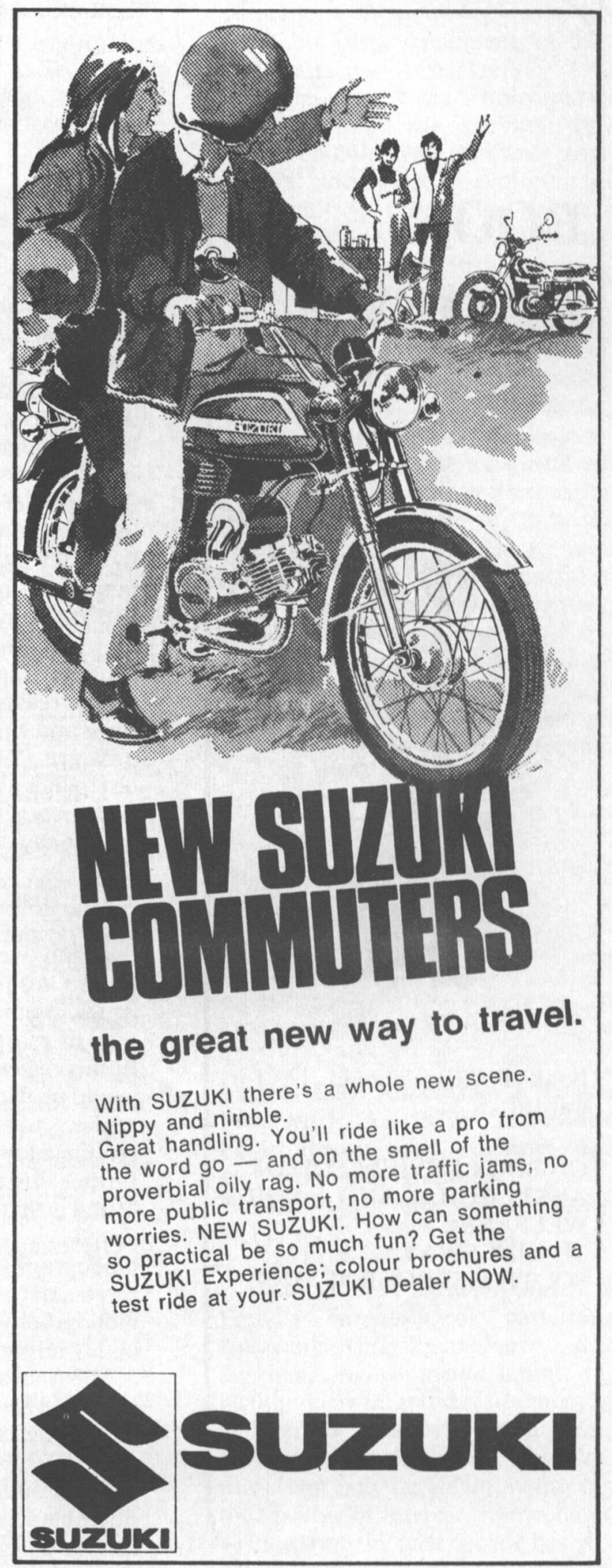

